\title{
Isolation. screening and identification of ligno-cellulolytic fungi from northern central Morocco
}

\author{
Hasna Nait M’barek ${ }^{(1)}$. Behnam Taidi ${ }^{(2)}$. Touhami Smaoui ${ }^{(2)}$. Mohamed Ben Aziz ${ }^{(1)}$. \\ Aouatef Mansouri ${ }^{(1)}$. Hassan Hajjaj ${ }^{(1)}$
}

${ }^{(1)}$ Faculty of Sciences of Meknes. Laboratory of Plant Biotechnology and Molecular Biology. BP 11201 Zitoune Meknes (Morocco) - Cluster of Competency «Agri-food. Safety and Security». IUC VLIR-UOS. Moulay Ismail University. Marjane 2. BP 298. Meknes (Morocco).E-mail: h_hajjaj@yahoo.com

(2) CentraleSupélec. SFR Condorcet FR. CNRS 3417. Paris-Saclay University. European Center of Biotechnology and Bioeconomy (CEBB) - LGPM. 3 rue des Rouges Terres. 51110 Pomacle (France).

Received 14 July 2018, accepted 31 July 2019, available online 10 October 2019.

This article is distributed under the terms and conditions of the CC-BY License (http://creativecommons.org/licenses/by/4.0)

Description of the subject. Extracellularenzymes from filamentous fungi are increasingly used in eco-friendly biotransformation processes. Their relevant technological role and their stability towards extreme process conditions make of them the first sustainable solution for the elaboration of bio-based products from biomass conversion.

Objectives. This paper describes the isolation of filamentous fungi from decaying plant material in the region of Meknes (northern central Morocco) and the assessment of their ability to breakdown lignocellulose. The objective is to select performant fungi with enzymatic machinery adapted to local environment and with potential for the breakdown of the regional specific lignocellulosic by-products into potentially high-value molecules.

Method. Cereals. decaying wood. olive-pomace and -pulp and their composts were used to isolate ligno-cellulolytic fungi. One hundred twenty-seven pure strains were isolated and screened at $25^{\circ} \mathrm{C}$ on selective media with cellulose or lignin as the sole carbon source. Performant strains were validated for the production of lignocellulolytic enzymes and identified using molecular technique.

Results. Twenty-eight fungi had mycelial diameter on cellulose $\geq 6 \mathrm{~cm}$ and cellulolytic index $\geq 0.9$. Twenty-two strains had the same profile on lignin medium. The production of endoglucanase. lignin peroxidase and manganese peroxidase enzymes was confirmed in performant strains using qualitative assay and molecular identification revealed that the best performing fungi were Mucor circinelloides. Mucor racemosus. Penicillium brasilianum. Penicillium crustosum. Paecilomyces sp.. Fusarium oxysporum. Fusarium solani. Aspergillus fischeri. Curvularia spicifera. Humicola grisea. Trichoderma atroviride and Cosmospora viridescens. Measurement of ligno-cellulolytic activities revealed that Penicillium and Fusarium strains mainly from wood decay and compost had the best profiles among performing strains.

Conclusions. Isolated fungi are high decomposers of biomass and represent a prominent solution to develop green bioprocesses in the region.

Keywords. Lignocellulose. biomass. filamentous fungi. cellulase. biotechnology. bioenergy. extracellular enzymes. Morocco.

Isolement. criblage et identification de souches ligno-cellulolytiques fongiques de la région nord-centre du Maroc Description du sujet. Les enzymes extracellulaires des champignons filamenteux sont de plus en plus utilisées dans la biotransformation respectueuse de l'environnement. Leur rôle technologique pertinent et leur stabilité vis-à-vis des procédés limites en font la première solution durable pour élaborer des produits biosourcés issus de la conversion de la biomasse.

Objectifs. Cet article traite de l'isolement de champignons filamenteux dans la région de Meknès (centre du Maroc) et de l'évaluation de leur capacité à décomposer la ligno-cellulose. L'objectif est de sélectionner des champignons performants dotés d'une machinerie enzymatique adaptée à l'environnement local et présentant un potentiel pour la décomposition des sous-produits ligno-cellulosiques spécifiques de la région en molécules à haute valeur ajoutée.

Méthode. Céréales. bois pourri. grignons/pulpe d'olive et leurs composts ont été utilisés pour isoler les champignons lignocellulolytiques. Cent vingt-sept souches pures ont été isolées et criblées à $25^{\circ} \mathrm{C}$ sur milieux sélectifs avec cellulose ou lignine comme uniques sources de carbone. Les souches performantes ont été validées pour produire les enzymes ligno-cellulolytiques et identifiées avec les techniques moléculaires. 
Résultats. Vingt-huit champignons avaient un diamètre mycélien sur cellulose $\geq 6 \mathrm{~cm}$ et un indice cellulolytique $\geq 0.9$. Vingt-deux avaient le même profil sur lignine. La production d'endoglucanase. lignine peroxydase et manganèse peroxydase a été qualitativement confirmée chez les souches performantes et leur identification moléculaire a révélé que ces champignons étaient Mucor circinelloides. Mucor racemosus. Penicillium brasilianum. Penicillium crustosum. Paecilomyces sp.. Fusarium oxysporum. Fusarium solani. Aspergillus fischeri. Curvularia spicifera. Humicola grisea. Trichoderma atroviride et Cosmospora viridescens. La mesure des activités ligno-cellulolytiques a révélé que les souches de Penicillium et de Fusarium provenant principalement du bois pourri et du compost présentaient les meilleurs profils parmi les souches performantes.

Conclusions. Les champignons isolés sont des décomposeurs actifs de biomasse et représentent une solution pertinente pour développer les bioprocédés verts dans la région.

Mots-clés.Lignocellulose. biomasse.champignons filamenteux. cellulase. biotechnologie.bioénergie.enzymes extracellulaires. Maroc.

\section{INTRODUCTION}

The current economic and industrial model. with its heavy reliance on mineral materials and energy sources is fast becoming untenable. On one hand the continuous production of waste. notably $\mathrm{CO}_{2}$. on the other. the accumulations of difficult-to-recycle products. are making it evident that this mode of function cannot continue indefinitely without serious environmental damage. One way to address this emerging problem is to increasingly rely on biotechnology to provide solutions that are more in tune with the natural world. Biotechnology is nowadays the first option capable of supplying the world with new and innovative alternatives to face environmental challenges and promote a green and sustainable industrial approach.

Industrial or white biotechnology aims to transform materials through the use of biological agents such as microorganisms or enzymes (Zhao et al.. 2013). It can open up the way to the development and marketing of new high-value molecules that would otherwise be very difficult to produce from fossil raw materials. Additionally. these specific and biotechnologically derived products may be more socially acceptable with lower environmental and human health impact. The global market for sustainable products is growing steadily and is estimated at over 20 billion euros in 2025 (Kircher. 2012).

The amount of plant cellulose formed each year is estimated at several billion tons. and constitutes the first potential source of available carbon on earth (Das \& Kumar Singh. 2004). In Morocco. the region of Meknes is located in the northern center and is characterized by the production of huge amounts of agricultural waste and industrial byproducts. It is the first national olive and cereals producer with more than 80.000 tons $\cdot y e r^{-1}$ for the latter (MAPM. 2017). The valorization of these lignocellulosic biomasses constitutes a big step towards "closing the loop" and is of economical challenge for the country. since those byproducts are merely used as direct combustibles.
Degradation and assimilation of plant cell walls by microorganisms is a complex process involving the synergistic action of a wide variety of organisms and their extracellular enzymes. The plant cell wall is mainly composed of complex polysaccharides (cellulose. hemicellulose. pectin). which constitute a dense. lignin coated multifunctional phenolic polymer (Hamelinck et al.. 2005; Xu et al.. 2013). Fungi secrete a range of extracellular enzymes in order to degrade this diversity of biopolymers into easy to assimilate oligomers and monomers. These enzymes include different proteases. (hemi-) cellulases. amylases. chitinases. esterases and lipases (Visser et al.. 2011). The considerable role of fungi in the global carbon cycle. the importance of their enzymatic arsenal for their survival and use of these enzymes in numerous biotechnological processes have resulted in a growing number of studies for understanding and characterizing their modes of action. Fungal ligno-cellulolytic enzymes primarily consist of ligninases with oxidative and peroxidative character (Wertz. 2010) and hydrolases that attack plant polysaccharides such as cellulose. hemicellulose. pectin and starch. Molds are able to colonize a wide variety of plants due to this enzymatic diversity and performance. capable of modifying what is essentially a very stable substrate (Archer et al.. 2008; Zhao et al.. 2013). Several studies have shown that infection of plant biomass by filamentous fungi is associated with the production of cell wall degrading enzymes (Archer et al.. 2008; Zhao et al.. 2013). thus. decaying plant material is an appropriate ecological niche for the isolation of fungal strains with biotechnologically interesting enzymatic potential.

Several fungal species have been reported for their ability to degrade lignocellulosic compounds: Penicillium chrysogenum (Rodriguez et al.. 1996). Fusariumoxysporum (Rodriguezetal.. 1996). Fusarium solani (Rodriguez et al.. 1996). Penicillium citrinum (Singhania et al.. 2010). Trichoderma reesei (Singhania et al.. 2010) and Mucor cirinelloidens (Singhania et al.. 2010). Some of the latter are environmental wild 
species and others were metabolically engineered to fit the industrial application.

A wide variety is already in use in the high industrial scale in applications for deriving value from fungal hydrolases and ligninases. Current applications include animal feed. the pulp and paper industry. textile. detergent production. biofuels and other sectors (Kirk et al.. 2002; Archer et al.. 2008). Fungal enzymes are applied either as biocatalysts to decompose biomass and wastes (biogas/bioenergy production after fermentation of released sugars. digestibility improvement of animal feed) or as technological agents (to enhance the oxidation power of detergents. finishing of textile. decolorization or bleaching) (Kirk et al.. 2002; Das \& Kumar Singh. 2004; Hamelinck et al.. 2005; Olukosi et al.. 2007; Chandra et al.. 2012). The feed sector abounds with examples of incorporation of hydrolases to improve bioavailability of nutrients and xylanase cocktails from Aspergillus and Trichoderma are the most used so far (Olukosi et al.. 2007). Other interesting lignin-derived molecules are also generated during the enzymatic attack and are used as food additives (vanillic acid. vanillin) or platform molecules for the green chemistry (furfural. HMF. ferrulic acid) (Das \& Kumar Singh. 2004).

In Morocco. the development of the lignocellulose valorization sector is limited by the high cost of enzymatic cocktails that are generally produced abroad and the limited scientific knowledge in the field. Consequently. the search for endemic strains with efficient enzymatic arsenal is of major economic importance for the country.

In this work. we aim to study fungal diversity in the region of Meknes by isolating from environmental samples of plant materials and byproducts collected. We aim also at characterizing the enzymatic potential of those strains to drive value from abundant nonvalorized biomasses and wastes. The characterization of new high potential strains can constitute a clue in the development and the enhancement of a green industrial policy in the region.

\section{MATERIALS AND METHODS}

\subsection{Sample collection}

Ait Souala and Guerrouane areas were selected as representative sites for regional production of cereals and their processed products. Fifteen samples of soft wheat. durum. barley grains and twelve others of their processed products (flour and semolina) were collected (Mansouri et al.. 2014). Cereal grains were sampled on a rectangular plan in plots of 1 ha each and the distance between two samples was of $50 \mathrm{~m}$ to ensure spatial coverage. Sampling was conducted during three successive years: 2012. 2013 and 2014 in different seasons. Storage cereals and processed derivatives were directly taken from silos of flourmills and all samples were stored at $-5{ }^{\circ} \mathrm{C}$ prior to analysis. Rotten forest wood: white. brown and soft rot were also collected for this study. Different sampling points in the forest of Azrou-Ifrane in the northern west of Morocco were chosen. Olive dry pomace. pulp and their compost were directly taken from olive oil processing industries with the biggest production capacity in our geographical delimitation.

\subsection{Isolation. purification and conservation of strains}

In order to select sporulating and more robust fungi. samples were first disinfected in a $0.2 \%$ sodium chloride solution for $3 \mathrm{~min}$. rinsed thrice with three times their original volume of sterile distilled water and randomly chosen to inoculate Czapek Agar petri dishes. Czapek Agar is a non-selective growth medium with a high carbon to nitrogen ratio and a neutral $\mathrm{pH}$. enabling easy growth of a large range of fungi with unspecific nutritional requirements but at the same time favoring fungal rather than bacterial growth (O'Donovan et al.. 2013).

Petri dishes were incubated at $25{ }^{\circ} \mathrm{C}$ for seven days and the fungi were isolated in apparently pure single strain form through successive subcultures. Spore suspensions of the latter were prepared using oneweek-old cultures. $10 \mathrm{ml}$ sterile deionized water and 20 sterile glass beads ( $5 \mathrm{~mm}$ diameter. Sigma) per plate applying an orbital movement to form a rich spore suspension. Each spore solution was stored separately in sterile glycerol cryovials at $-20{ }^{\circ} \mathrm{C}$.

\subsection{Screening of ligno-cellulolytic fungi}

Screening was performed by growing each isolate on Czapek Agar with microcrystalline cellulose (Avicel®. Sigma) or lignin (Alkali with no reducing sugars CAS 8068-05-1. product reference 471003. Sigma) at a concentration of $3 \mathrm{~g} \cdot \mathrm{l}^{-1}$ and as the sole carbon and energy source. Isolates were incubated at $25^{\circ} \mathrm{C}$ and monitored for 14 days compared to control with sucrose. Every two days. the colony diameter was measured in two perpendicular marked positions and growth kinetics represented as the mean of two measurements. The potential of each fungus to decompose cellulose and/ or lignin was estimated using lignocellulolytic index calculated with the following formula:

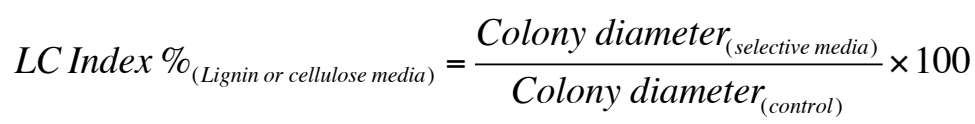


In addition. a nominal indicator for colony formation mode (aspect and density of mycelium) using four descriptors was taken into consideration (Table 1).

After 14 days of incubation. fungi that showed a growth diameter on selective media superior or equal to control with a high mycelium density were considered "ligno-cellulolytic performant" strains.

To maintain a positive activity over time for interesting isolates. the number of successive subcultures was limited as it can cause activity loss by occurring mutations (Maheshwari \& Navaraj. 2008). A second practice consisted on the conservation of strains directly from selective media to ensure the conservation of an actively induced ligno-cellulolytic phenotype. Cryovials were stored at $-20{ }^{\circ} \mathrm{C}$ and all above parameters were considered to select the most interesting fungi.

\subsection{Qualitative validation of cellulase and ligninase production by fungi}

After first screening. the best performing isolates were qualitatively checked for the production of ligno-cellulolytic enzymes as described by Pointing (1999). Four activities were assessed using three tests: Cellulose Agar Clearance (for total cellulase cocktail activity). Dye Staining of low viscosity CarboxyMethyl Cellulose (CMC) Agar (for endoglucanase activity. EG). and Azure B Agar Clearance (for lignin peroxidase and manganese-dependent peroxidase. LiP \& MnP). Briefly. the filamentous fungi were grown on a solid Cellulose or Lignin Basal Media (CBM or LBM) supplemented with the enzyme substrate at an appropriate concentration (w/v): $4 \%$ Cellulose Avicel ${ }^{\circledR}$ (Sigma). 2\% low viscosity CMC (Sigma) and $0.1 \%$ Azure B (Sigma). respectively. The cultures were monitored for 10 days. Positive results were observed around the colony as a "clearance" on the cellulose medium. yellow to dark orange halo zone after staining with Congo red (Sigma) and destaining with $1 \mathrm{M} \mathrm{NaCl}$ for endoglucanase test or a clearance of the Azure B dye for LiP \& MnP activities.

\subsection{Morphological identification of fungal isolates}

Macroscopic and microscopic observations of oneweek-old fungal colonies were used for primary identification: radial colony growth rate. mycelium aspect and colony/reverse color were the basic criteria for the initial characterization of each species. Microscopy enabled a closer observation of hyphae. conidia. sporing structures and subsequent fruiting bodies. Fungal isolates were grown in three basic media as described by Pitt et al. (2009): Czapek Yeast Agar (CYA). Malt Extract Agar (MEA) and 25\% Glycerol Nitrate Agar (G25N). Every isolate was grown simultaneously on the later at three different temperatures $\left(5{ }^{\circ} \mathrm{C} .25{ }^{\circ} \mathrm{C}\right.$ and $\left.37{ }^{\circ} \mathrm{C}\right)$ to assess the temperature tolerance of the strain. Petri dishes incubated at $37{ }^{\circ} \mathrm{C}$ were enclosed in polyethylene bags to diminish water evaporation from the medium. Identification key described by Pitt \& Hocking (2009) was followed step by step to identify fungal isolates.

\subsection{Molecular identification}

DNA extraction. Twenty performant fungi were identified with molecular techniques. One-week-old culture was subject to DNA extraction using ISOLATE II Plant DNA Kit (BIOLINE) according to the manufacturer's instructions. The DNA concentration was measured with NanoDrop ${ }^{\mathrm{TM}}$ ND-8000 Spectrophotometer system (Thermo Scientific) and the quality of nucleic acid checked by $\mathrm{A}_{260} / \mathrm{A}_{280}$ absorbance coefficient.

Polymerase Chain Reaction (PCR). The identification of fungi was performed using the Inter Transcribed Spacer for nuclear ribosomal DNA primer pairs (ITS1/ ITS4) (ITS1: TCC GTA GGT GAA CCT TGC GG. ITS4: TCC TCC GCT TAT TGA TAT GC) (White et al.. 1990). MyTaq ${ }^{\mathrm{TM}}$ DNA Polymerase Kit (BIOLINE) was used for the PCR reactions: each reaction tube contained $5 \mu \mathrm{L}$ of $2 \times$ reaction buffer. $1 \mu \mathrm{L}$ of each $10 \mu \mathrm{M}$ forward and reverse primers solution. $0.2 \mu \mathrm{L}$ of MyTaq $^{\mathrm{TM}}$ DNA Polymerase $5 \mathrm{U} \cdot \mu \mathrm{L}^{-1} .150 \mathrm{ng}$ sample

Table 1. Nominal notation for mycelium density - Notation nominale de la densité mycélienne.

\begin{tabular}{|c|c|c|}
\hline Notation & Mycelium formation descriptor & Description \\
\hline 1 & No observed growth (NOG) & $0 \%$ growth \\
\hline 2 & Fine filaments & $\begin{array}{l}\text { Non dense center of the plate. just some dispersed and hyaline } \\
\text { fungal filaments }\end{array}$ \\
\hline 3 & Dense in the center and filamentous at the ends & $\begin{array}{l}\text { Dense center area not exceeding } 50 \% \text { of the whole mycelium } \\
\text { surface area }\end{array}$ \\
\hline 4 & Completely dense & $\begin{array}{l}\text { Dense center area equal or more than } 50 \% \text { of the whole } \\
\text { mycelium surface area }\end{array}$ \\
\hline
\end{tabular}


DNA and a sufficient quantity of Milli-Q ${ }^{\circledR}$ water to reach $25 \mu \mathrm{L}$ final volume. PCR program was set as follows: $95^{\circ} \mathrm{C}$ for $1 \mathrm{~min} .35 \mathrm{X}\left(95^{\circ} \mathrm{C}\right.$ for $15 \mathrm{~s} .57^{\circ} \mathrm{C}$ for $20 \mathrm{~s} .72{ }^{\circ} \mathrm{C}$ for $15 \mathrm{~s}$ ). $72{ }^{\circ} \mathrm{C}$ for $3 \mathrm{~min}$. The reaction was conducted using Veriti ${ }^{\mathrm{TM}}$ Thermal cycler (Applied Biosystems $^{\mathrm{TM}}$ ).

Sequencing and treatment of reads. PCR products were purified using ExoSAP-IT ${ }^{\mathrm{TM}}$ PCR Product Cleanup Reagent (Applied Biosystems ${ }^{\mathrm{TM}}$ ) and amplicons verified by electrophoresis on $1 \%$ agarose gel. Sequencing was established in both directions using the same primer pairs and following the supplier recommendations for BigDye ${ }^{\circledR}$ Terminator Cycle Sequencing Kit (Applied Biosystems ${ }^{\mathrm{TM}}$ ).

Sequences were analyzed using Geneous Pro 10.2.2 and MEGA 6.06 softwares as described by Bast (2013). Reads were aligned using the CLUSTALW® Algorithm and results were checked and corrected manually when necessary. Consensus sequences were then generated. blasted and submitted to Genbank. Only hits with a threshold $\geq 97 \%$ of pairwise similarity were admitted for further assessment of species delineation. All gaps were considered as missing data and the bestfit nucleic acid substitution model showing the lowest BIC value was selected for phylogeny reconstruction. Neighbor-Joining tree-construction model was used and confidence levels of the branching points determined by a bootstrap analysis with 1.000 replications. All steps were conducted according to reference guidelines (Edgar \& Batzoglou. 2006; Gregory. 2008; Bast. 2013; Hall. 2013).

\subsection{Measurement of cellulase and ligninase activities in submerged fermentation}

The best performing strains were grown in Czapek liquid with cellulose or lignin as the sole carbon source. For redundant species. only one was selected among same strains from same substratum. Two hundred fifty milliliters flasks were used with a working volume of $100 \mathrm{ml}$. After inoculation with $1 \mathrm{~cm}$ diameter disk from one-week-old culture. they were incubated at $25^{\circ} \mathrm{C}$. $120 \mathrm{rpm}$ for 5 days. At end test point. samples were collected. centrifuged at $4{ }^{\circ} \mathrm{C}$. $3.000 \mathrm{rpm}$ for $15 \mathrm{~min}$ and supernatants recovered for protein and lignocellulolytic activities measurements. Proteins were quantified with Lowry method using Pierce ${ }^{\mathrm{TM}}$ Modified Lowry Protein Assay Kit (Thermo Scientific ${ }^{\mathrm{TM}}$. France) and according to the manufacturer instructions. Cellulase activity was measured as Filter Paper Assay (FPA). endoglucanase (CMCase) and $\beta$-glucosidase (cellobiase) activities using standard protocols of the International Union of Pure and Applied Chemistry (IUPAC) (Ghose. 1987). Briefly. each enzyme activity was assayed by incubating a precise volume of enzyme supernatant in the presence of its specific substrate: $50 \mathrm{mg} 1^{\text {st }}$ grade Whatman filter paper. $2 \%$ low viscosity Carboxymethyl Cellulose and $50 \mathrm{mM}$ cellobiose. respectively. All $\mathrm{pH}$ protocol conditions were respected and the mixture was incubated at $50{ }^{\circ} \mathrm{C}$ for $1 \mathrm{~h}$ (FPA) or $30 \mathrm{~min}$ (endoglucanase and $\beta$-glucosidase activities). Reactions were terminated adding Dinitrosalicylic acid modified reagent (DNS) (Miller et al.. 1960) and mixtures were incubated for $15 \mathrm{~min}$ at $100{ }^{\circ} \mathrm{C}$. Reducing sugars were quantified at $540 \mathrm{~nm}$ as D-glucose equivalent sugars using a standard curve. Laccase. lignin peroxidase and manganese dependent peroxidase activities were measured according to Hariharan \& Nambisan (2013) following the oxidation of 2.2'-azino-bis(3-ethylbenzothiazolin6-sulphonic acid) (ABTS). Veratryl alcohol and phenol red. respectively. Enzyme activities were expressed as $\mathrm{IU} \cdot \mathrm{ml}^{-1}$. defined as the amount of enzyme capable of catalyzing the transformation of $1 \mu \mathrm{mol}$ of substrate per minute under standard protocol conditions. All samples were analyzed in triplicate against enzyme and substrate blanks.

\subsection{Statistical analysis of data}

The data are presented as mean \pm standard deviation of triplicate samples. The least significant difference (LSD) was computed using Tukey's test under IBM SPSS Statistics 22 software. All graphical presentations were drawn using the same software.

\section{RESULTS}

\subsection{Isolation of fungi. screening and validation of ligno-cellulolytic activities}

One hundred twenty-seven pure fungal isolates were obtained. conserved in cryovials and stored at $-20^{\circ} \mathrm{C}$. They belonged to the following genera: Penicillium (58.6\%). Fusarium (11.7\%). Aspergillus (7.8\%). Trichoderma (5.5\%). Ulocladium (2.3\%). Chaetomium (1.6\%). Rhizopus (1.6\%). Alternaria (0.8\%). Epicocum $(0.8 \%)$. Botrytis (0.8\%). Geotrichum (0.8\%). Cladosporium (0.8\%). Monascus $(0.8 \%)$ and some non-identified strains (6.3\%) (Figure 1). In our study. Penicillium. Fusarium and Aspergillus genera were the most isolated from samples. They were found in all ligno-cellulosic substrates with a noticeable presence in cereals and decaying wood (Figure 1). Among all substrates. wood exhibited an important mycological diversity with the isolation of several fungal genera.

At the end of the screening test. fungi from rotten wood. compost and olive pomace and pulp (Olive $\mathrm{P} \& \mathrm{P})$ had the best ligno-cellulolytic growth profile (Figure 2a). in particular: Fusarium. Penicillium. 


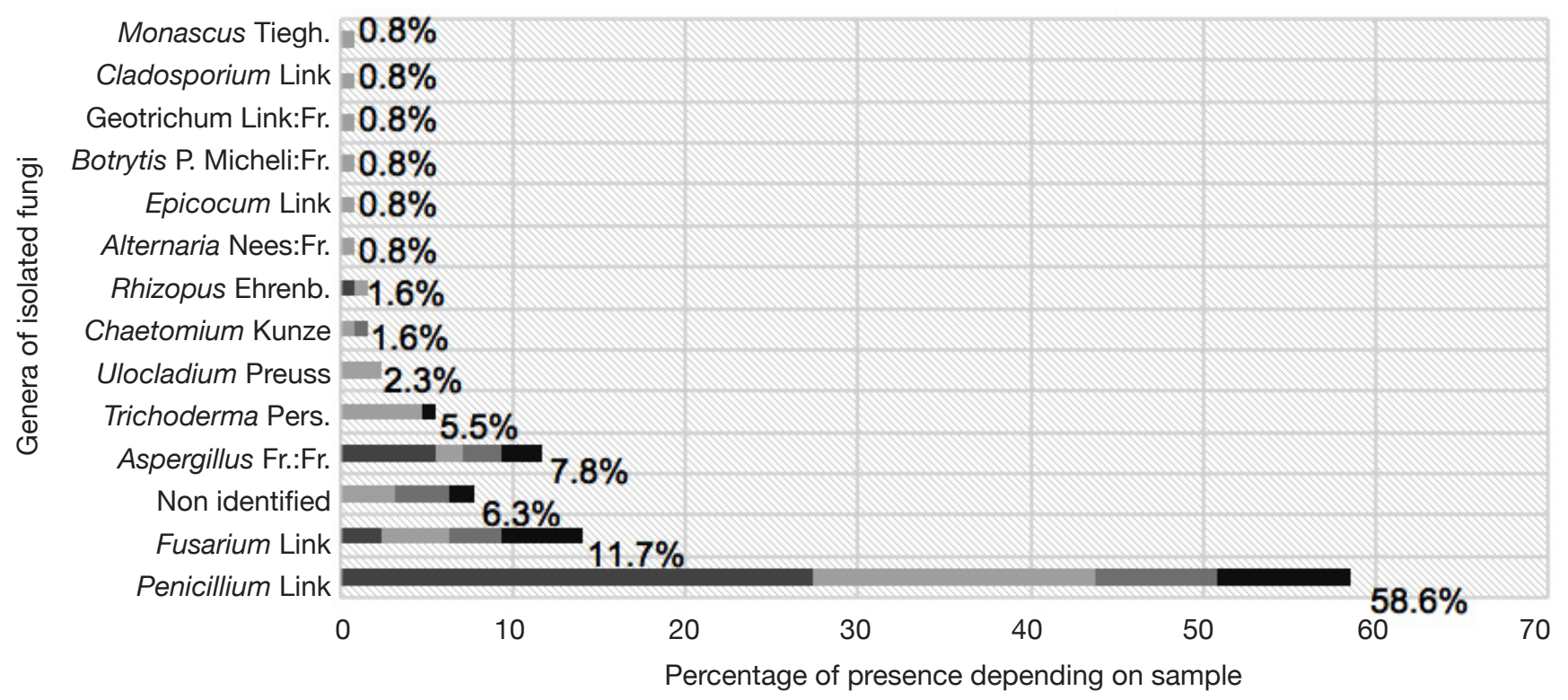

- Cereals \& processed products

Rotten wood

- Olive pomace \& pulp

Compost

Figure 1. Distribution of genera of fungi isolated from the region of Meknes in central Morocco - Distribution des genres de champignons filamenteux isolés de la région de Meknès au centre du Maroc.

Aspergillus. Trichoderma and some Epicoccum. Ulocladium and Chaetomium isolates as identified using morphological technique. The measured diameter of the spherical mycelial growth area for each isolate was quite different depending on the genus and the original sample. Twenty-eight fungi grew well on cellulose medium comparably to control and presented a mycelial area diameter $\geq 6 \mathrm{~cm}$ (ranging from 6.5 to $9.2 \mathrm{~cm}$ ) after 12 days of incubation. Their Cellulolytic Index was higher than 0.9 showing the comparable growth profiles on cellulose medium and control. Twenty-two strains presented the same profile for their development on lignin: mycelial diameter ranging from 7 to $9.2 \mathrm{~cm}$ and Lignolytic Index $\geq 0.95$. Among all performant ligno-cellulolytic strains. Fusarium was the most invading genus and the fastest growing on both cellulose and lignin (Figure $\mathbf{2 b}$ ).

Those performant fungi from the screening step had positive results for cellulase and/or ligninase production on qualitative solid plates. Figure 2c illustrates endoglucanase activity results of three of them. This qualitative confirmation enabled the determination of the enzymatic profile of each strain: cellulolytic (endoglucanase + ) and/or lignolytic $(\mathrm{LiP} \& \mathrm{MnP}+)$.

\subsection{Molecular identification of performant strains}

DNA extraction protocol yielded a mean concentration of $52.5 \mathrm{ng} \cdot \mu \mathrm{L}^{-1}$ and $\mathrm{A} 260 / 280$ coefficient ranged from 1.65 to 1.92 assessing high quality of extracted
DNA. Subsequently. universal ITS1/4 primer pairs gave satisfactory amplification with the selected PCR conditions and agarose gel migration. The 20 identified performant fungi represented 12 distinguished species: Mucor circinelloides. Mucor racemosus. Penicillium brasilianum. Penicillium crustosum. Paecilomyces sp.. Fusarium oxysporum. Fusarium solani. Aspergillus fischeri. Curvularia spicifera. Humicola grisea. Trichoderma atroviride and Cosmospora viridescens with identity scores of $99-100 \%$ for most of them (Table 2). Phylogenetic analysis of ITS sequences showed that Fusarium sp. strain (85) was closely related to Fusarium solani (102) with $100 \%$ bootstrap score. hence. it could be same species or one of its varieties or formae speciales. Alike. Mucor fungi (38 and 62) were phylogenetically very close. Figure 3 represents results of Neighbor-Joining phylogeny construction with illustrations of performant species.

\subsection{Activities measurement in submerged fermentation}

After five days incubation in flasks. both Fusarium solani strains (85 and 102) achieved interesting protein production levels. For total cellulase activity. Penicillium crustosum (64) was the highest producer among all with total activity achieving $9.7 \mathrm{IU} \cdot \mathrm{ml}^{-1}$. Other cellulolytic strains came after showing also good cellulolytic profile. respectively: Fusarium solani (102). Paecilomyces sp. (46) and Cosmospora viridescens (89). The cellulolytic potential of $F$. solani 
a

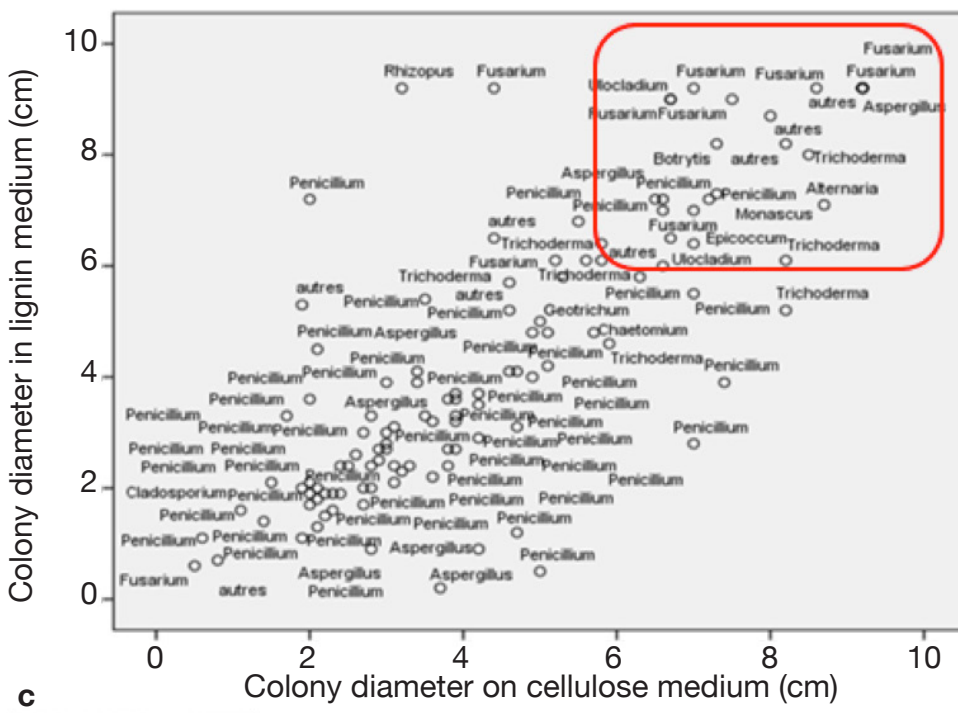

b

\begin{tabular}{|c|c|c|c|c|c|c|c|c|}
\hline Fungus & Genus & subetratum & $a_{k}$ & $a$ & cd & L.I & CNN & L.N \\
\hline 38 & Ulocladium & Wood deczy & - & 9 & - & 1 & - & 3 \\
\hline 39 & Penicillum & Wood decay & 7,3 & 7,3 & 1,18 & 1,18 & 3 & 3 \\
\hline 46 & Fusanum & Wood deçy & 7,5 & 9 & 1,47 & 1,76 & 4 & 4 \\
\hline 52 & Anernarla & Wood deczy & 8,7 & - & 1,05 & - & 3 & - \\
\hline 55 & Penicillum & Wood decay & 7,4 & - & 1,19 & - & 3 & - \\
\hline 57 & Penicillum & Wood decay & 7 & - & 1,19 & - & 3 & - \\
\hline 61 & Eplooccum & Wood decay & 7 & - & 1,11 & - & 4 & - \\
\hline 62 & $\mathrm{NI}$ & Wood deczy & 7.2 & 7,2 & 1 & 1 & 3 & 3 \\
\hline 64 & Penicillum & Wood decay & 7 & - & 1.52 & - & 3 & - \\
\hline 66 & Trichoderma & Wood decay & 8,5 & - & 0,92 & - & 4 & - \\
\hline 67 & Ulocladlum & Wood decay & 6,6 & 7 & 0,94 & 1 & 4 & 3 \\
\hline 76 & Fusanium & Wood decay & 9.2 & 9,2 & 1 & 1 & 3 & 3 \\
\hline 77 & $\mathrm{NI}$ & Wood decay & 6,6 & - & 1 & - & 4 & - \\
\hline 85 & Fusanum & Wood deczy & - & 8,2 & - & 1 & - & 3 \\
\hline 87 & $\mathrm{NI}$ & Wood deçy & 8.2 & 8,2 & 0,95 & 0,95 & 2 & 2 \\
\hline 88 & Trichoderma & Wood deczy & 8,2 & - & 1 & - & 4 & - \\
\hline 89 & Trichoderma & Wood decay & 8.2 & - & 1,3 & - & 4 & - \\
\hline 95 & Fusanum & Compost & - & 9,2 & - & 1 & - & 3 \\
\hline 96 & Asperglllus & Compost & 6,6 & 7,2 & 0,92 & 1 & 3 & 3 \\
\hline 100 & Fusanum & Compost & 9.2 & 9,2 & 1.28 & 1,28 & 4 & 4 \\
\hline 101 & Fusanium & Compost & 8,6 & 9,2 & 0,99 & 1,06 & 3 & 3 \\
\hline 102 & Fusanum & Compost & 9.2 & 9,2 & 1,28 & 1,28 & 4 & 4 \\
\hline 106 & $\mathrm{NI}$ & Compost & 9.2 & 9,2 & 1 & 1 & 3 & 3 \\
\hline 107 & Chaetomium & Ollve P\&P & 9,2 & 9,2 & 1,28 & 1,28 & 3 & 3 \\
\hline 108 & Fusanum & Ollve P\&P & 9.2 & 9,2 & 1.28 & 1,28 & 3 & 3 \\
\hline 109 & Fusanum & Oltve P\&P & 9.2 & 9,2 & 1 & 1 & 2 & 3 \\
\hline 110 & Fusanium & Ollve P\&P & 9,2 & 9,2 & 1 & 1 & 3 & 3 \\
\hline 111 & Fusarium & Ollve P\&P & 9,2 & 9,2 & 1 & 1 & 2 & 2 \\
\hline 114 & Aspergillus & Ollve P\&P & 9,2 & 9,2 & 1,02 & 1,02 & 2 & 2 \\
\hline 115 & NI & Ollve P\&P & 8 & 8,7 & 0,96 & 1,05 & 2 & 2 \\
\hline 117 & Asperglllus & Ollve P\&P & 6,5 & 7,2 & 0,9 & 1 & 3 & 3 \\
\hline
\end{tabular}

Figure 2. Screening of ligno-cellulolytic fungi - Criblage de champignons filamenteux ligno-cellulolytiques .

a. Dispersion of isolates depending on their colony diameter on cellulose and lignin solid media. after 14 days incubation at $25^{\circ} \mathrm{C}$. The red rectangle represents strains with colony diameter $\geq 6 \mathrm{~cm}-$ Dispersion des isolats en fonction du diamètre de leurs colonies sur milieu cellulosique et lignine solide. après 14 jours d'incubation à $25^{\circ} \mathrm{C}$. Le rectangle rouge représente les souches ayant un diamètre de colonie $\geq 6 \mathrm{~cm}$. b. Strains from the rectangle area classified according to their colony diameter in selective media. their calculated Ligno-Cellulolytic Index and the nominal notation for mycelial density. $\varnothing \mathrm{C}$ and $\varnothing \mathrm{L}$ : Colony diameter on cellulose and lignin media. respectively. C.I and L.I: Cellulolytic and Lignolytic Indexes. C.N and L.N: Notation of mycelial density on cellulose and lignin media. respectively - Les souches de la zone rouge classées en fonction du diamètre de leurs colonies sur les milieux sélectifs. leur indice ligno-cellulolytique calculé et la notation nominale de la densité mycélienne. $\emptyset \mathrm{C}$ et $\emptyset \mathrm{L}$ : diamètre des colonies sur milieux cellulose et lignine. respectivement; C.I et L.I : indices cellulolytique et lignolytique ; C.N et L.N : notation de la densité mycélienne sur milieux cellulose et lignine. respectivement. c. Qualitative assay for detection of endoglucanase activity using CMC Agar Clearance test (from left to right: isolates 64.67 and 77. respectively) - Essai qualitatif pour la détection de l'activité endoglucanase en utilisant le test CMC Agar Clearance (de gauche à droite : isolats 64.67 et 77 . respectivement).

(102) is mainly due to the production of endoglucanase and $\beta$-glucosidase enzymes. However. the high Filter Paper activity in Penicillium crustosum (64) and Paecilomyces sp. (46) suggest the synergistic action of endoglucanases and subsequent auxiliary enzymes that were probably produced and not investigated in this study. Lastly. cellulolytic cocktail of Cosmospora viridescens (89) contains only endoglucanases. Ligninases were expressed quite differently in performing fungi. Penicillium crustosum (64) and Fusarium oxysporum (76 and 106) were characterized for high laccase. lignin peroxidase and manganese dependent peroxidase activities. respectively. Table 3 gives more details of the measured enzymatic potential.

\section{DISCUSSION}

The occurrence of Penicillium. Fusarium and Aspergillus strains in cereals and wood decay is concordant with other studies. In Morocco. they were cited as field pathogens invading the growing seeds of cereals in the pre-harvest stage (Hajjaji et al.. 2004; Roussos et al.. 2006; Ennadir et al.. 2012) and were reported for the implication in complex breakdown of decaying wood. among a variety of other microbes (Blanchette. 1984; Eriksson et al.. 1990; Wertz. 2010; Berrin et al.. 2012).

The national park of Ifrane-Azrou in Morocco's middle Atlas is a $500 \mathrm{~km}^{2}$ natural escape known 
Table 2. Molecular identification of performant ligno-cellulolytic fungi isolated in central Morocco - Identification moléculaire des champignons ligno-cellulolytiques performants isolés au centre du Maroc.

\begin{tabular}{|c|c|c|c|c|}
\hline Fungi & Blast result & Best hit & Identity & GenBank Accessions \\
\hline 38 & Mucor circinelloides & LN809028.1 & $100 \%$ & MK956805 \\
\hline 39 & Penicillium brasilianum & MH377073.1 & $99 \%$ & MK956806 \\
\hline 46 & Paecilomyces sp. / Byssochlamys spectabilis & MF379654.1 / MF379646.1 & $100 \% / 100 \%$ & - \\
\hline 52 & Curvularia spicifera & LT631349.1 & $100 \%$ & MK956807 \\
\hline 55 & Penicillium brasilianum* & - & - & - \\
\hline 61 & Humicola grisea* & - & - & - \\
\hline 62 & Mucor racemosus & JN205928.1 & $96 \%$ & MK956808 \\
\hline 64 & Penicillium crustosum* & - & - & - \\
\hline 67 & Humicola grisea* & - & - & - \\
\hline 76 & Fusarium oxysporum & KY817522.1 & $100 \%$ & MK956809 \\
\hline 77 & Humicola grisea* & - & - & - \\
\hline 85 & Fusarium sp. & MG252776.1 & $98 \%$ & MK956810 \\
\hline 88 & Trichoderma atroviride* & - & - & - \\
\hline 89 & Cosmospora viridescens & KJ676148.1 & $99 \%$ & MK956811 \\
\hline 101 & Fusarium solani* & - & - & - \\
\hline 102 & Fusarium solani & MH377074.1 & $100 \%$ & MK956803 \\
\hline 106 & Fusarium oxysporum & MF457482.1 & $100 \%$ & MK956804 \\
\hline 107 & Fusarium solani* & - & - & - \\
\hline 117 & Aspergillus fischeri & MF401628.1 & $99 \%$ & MK956802 \\
\hline
\end{tabular}

*Identified in an external competent laboratory - identifiés par un laboratoire compétent externe.

Table 3. Protein concentration. cellulase and ligninase activities measured after five days incubation of fungal species in submerged fermentation - Concentration en protéines. activités cellulase et ligninase mesurées après cinq jours d'incubation en fermentation submergée.

\begin{tabular}{|c|c|c|c|c|c|c|c|}
\hline \multirow[t]{2}{*}{ Fungus } & \multirow{2}{*}{$\begin{array}{l}\text { Protein } \\
\left(\mu \mathrm{g} \cdot \mathrm{ml}^{-1}\right)\end{array}$} & \multicolumn{3}{|c|}{ Cellulase $\left(\mathrm{IU} \cdot \mathrm{ml}^{-1}\right)$} & \multicolumn{3}{|c|}{ Ligninase $\left(\mathrm{IU} \cdot \mathrm{ml}^{-1}\right)$} \\
\hline & & $\begin{array}{l}\text { Filter } \\
\text { paper } \\
\text { assay }\end{array}$ & $\begin{array}{l}\text { Endoglucanase } \\
\text { activity }\end{array}$ & $\begin{array}{l}\beta \text {-glucosidase } \\
\text { activity }\end{array}$ & $\begin{array}{l}\text { Laccase } \\
\text { activity }\end{array}$ & $\begin{array}{l}\text { Lignin peroxidase } \\
\text { activity }\end{array}$ & $\begin{array}{l}\text { Manganese } \\
\text { dependant } \\
\text { peroxidase } \\
\text { activity }\end{array}$ \\
\hline 38 & $532 \pm 6.4^{\mathrm{d}}$ & not detected & not detected & not detected & not detected & $0.91 \pm 0.1^{\mathrm{e}}$ & not detected \\
\hline 39 & $160 \pm 9.2^{\mathrm{h}}$ & $1.1 \pm 0.4^{\mathrm{g}}$ & $3.2 \pm 0.1^{\mathrm{b}}$ & $1.28 \pm 0.1^{\mathrm{a} . \mathrm{b}}$ & not detected & $1.61 \pm 0.1^{\mathrm{d}}$ & not detected \\
\hline 46 & $277 \pm 7.1^{\mathrm{f}}$ & $5.91 \pm 0.0^{c}$ & $1.8 \pm 0.1^{\mathrm{d}}$ & not detected & $0.28 \pm 0.0^{\mathrm{b}}$ & $2.45 \pm 0.2^{c}$ & $0.17 \pm 0.1^{\mathrm{a}}$ \\
\hline 52 & $776 \pm 13.4^{\mathrm{c}}$ & $1.71 \pm 0.1^{\mathrm{f}}$ & $1.31 \pm 0.1^{\mathrm{e}}$ & not detected & not detected & not detected & not detected \\
\hline 61 & $365 \pm 17.7^{e}$ & $1.74 \pm 0.1^{\mathrm{f}}$ & $1.3 \pm 0.1^{\mathrm{e}}$ & $1.46 \pm 0.1^{\mathrm{a}}$ & not detected & not detected & not detected \\
\hline 62 & $82.5 \pm 13.4^{\mathrm{i}}$ & $1.39 \pm 0.0^{\mathrm{f}}$ & $0.86 \pm 0.1^{\mathrm{f}}$ & not detected & not detected & not detected & $0.15 \pm 0.0^{\mathrm{a} . \mathrm{b}}$ \\
\hline 64 & $135 \pm 9.2^{\text {h.i }}$ & $9.69 \pm 0.0^{\mathrm{a}}$ & $1.46 \pm 0.1^{\text {d.e }}$ & not detected & $1.53 \pm 0.1^{\mathrm{a}}$ & not detected & not detected \\
\hline 76 & $204 \pm 9.9^{g . h}$ & $2.39 \pm 0.1^{\mathrm{e}}$ & not detected & $1.08 \pm 0.2^{\mathrm{b} . \mathrm{c}}$ & not detected & $7.45 \pm 0.1^{\mathrm{a}}$ & not detected \\
\hline 85 & $1,618 \pm 48.1^{\mathrm{a}}$ & not detected & not detected & not detected & not detected & not detected & $0.01 \pm 0.0^{\mathrm{b}}$ \\
\hline 88 & $279 \pm 6.4^{\mathrm{f}}$ & $0.63 \pm 0.2^{\mathrm{h}}$ & $0.19 \pm 0.0^{\mathrm{g}}$ & $0.84 \pm 0.2^{\text {c.d }}$ & not detected & not detected & not detected \\
\hline 89 & $166 \pm 9.2^{\mathrm{h}}$ & $4.02 \pm 0.2^{\mathrm{d}}$ & $9.49 \pm 0.2^{\mathrm{a}}$ & not detected & not detected & not detected & not detected \\
\hline 102 & $1513 \pm 29^{b}$ & $7.51 \pm 0.2^{\mathrm{b}}$ & $2.4 \pm 0.2^{\mathrm{c}}$ & $0.65 \pm 0.1^{\mathrm{d}}$ & $0.4 \pm 0.1^{\mathrm{b}}$ & not detected & not detected \\
\hline 106 & $776 \pm 9.2^{c}$ & $2.63 \pm 0.2^{\mathrm{e}}$ & $0.28 \pm 0.1^{\mathrm{g}}$ & $0.71 \pm 0.0^{\mathrm{d}}$ & not detected & $5.58 \pm 0.2^{b}$ & $0.28 \pm 0.1^{\mathrm{a}}$ \\
\hline 117 & $271 \pm 6.4^{\mathrm{f} g \mathrm{~g}}$ & $0.18 \pm 0.1^{\mathrm{h}}$ & $0.31 \pm 0.1^{\mathrm{g}}$ & not detected & not detected & $1.05 \pm 0.1^{\mathrm{e}}$ & not detected \\
\hline
\end{tabular}

Values followed by the same letter are not significantly different (LSD. 0.1\%) - Les valeurs suivies par la même lettre ne sont pas significativement différentes (LSD. $0.1 \%$ ). 


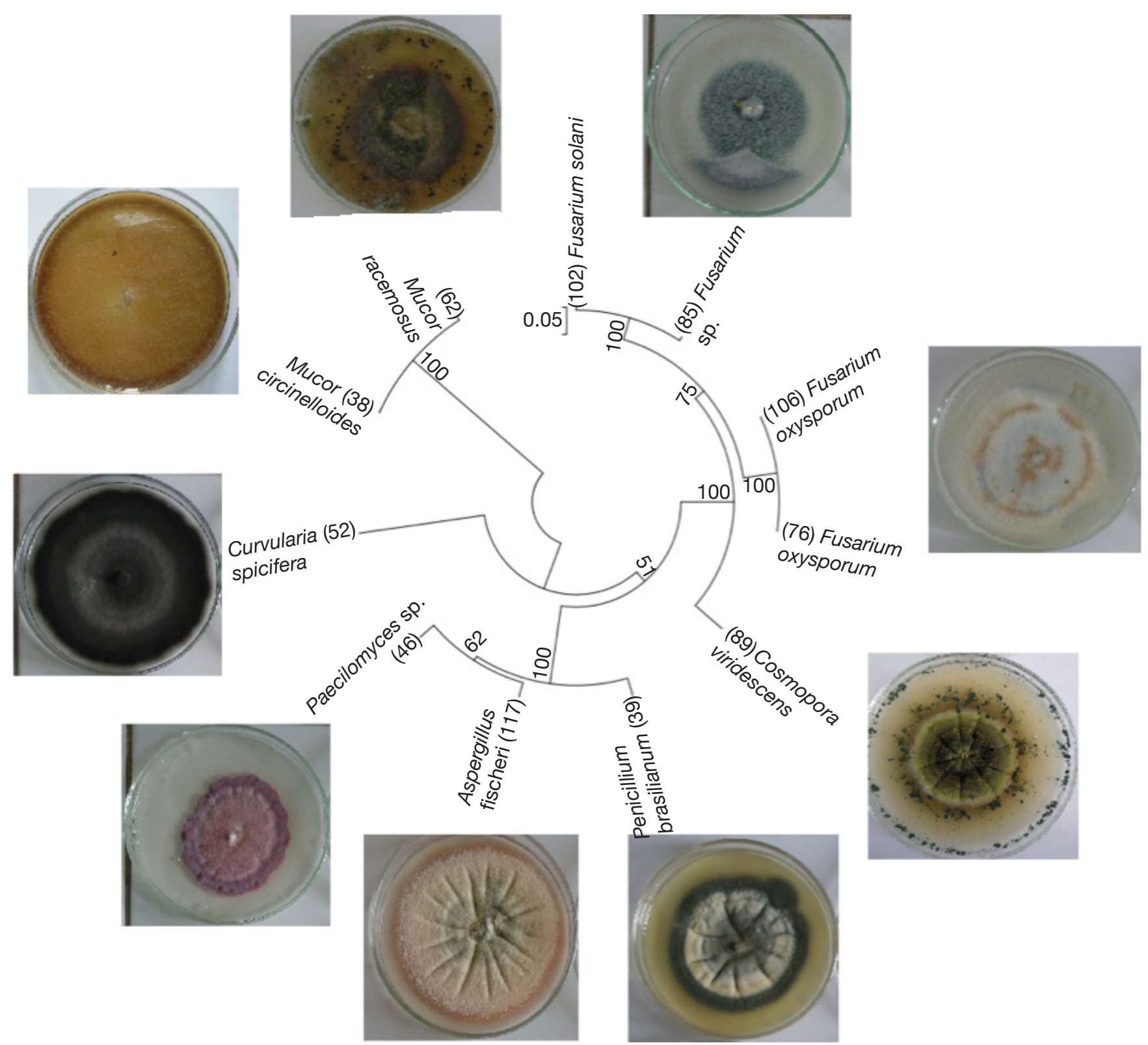

Figure 3. Phylogeny construction of the best performing ligno-cellulolytic species based on ITS sequences - Arbre phylogénétique des espèces ligno-cellulolytiques performantes contruit sur la base des séquences ITS.

Values on branching nodes represent the bootstrap score - Les valeurs sur les nouds de branchement représentent le score bootstrap.

for its high fauna and flora diversity. It houses the largest national cedar forest and is characterized by its humid and temperate climate in summer and icy in winter (Ministry of Environment. 2016). Forest wood from this region is a natural habitat for different microorganisms with potential biotechnological value and its colonization by fungi is tightly related to the production of extracellular Carbohydrate Active enZymes (CAZymes) and different ligninases (Zhao et al.. 2013; This work). In Morocco. very few studies aiming the identification of lignocellulose-degrading fungi were conducted so far. Zyani et al. (2009) and El Bergadi et al. (2014) identified cellulolytic Penicillium crustosum and Mucor racemosus in wood and paper samples from old Medina of Fez. However. no information was delivered concerning the ligninolytic activities of these fungi. Penicillium crustosum isolated in this study is special in regard to its high cellulolytic potential. Additionally. its laccase oxidizing activity is relevant for use in the decolorization of industrial effluents compared to other isolates (Hefnawy et al.. 2017). In bioethanol production. the first step of biomass deconstruction is catalyzed by xylanases from Paecilomyces genera 
and P.variotii is the most commonly used due to its interesting catalytic features (Yang et al.. 2006; Zerva Alexander et al.. 2014). However. its poorly diversified cocktail is process limiting and the pool is usually enhanced with $\beta$-glucosidases supplements from Trichoderma or Aspergillus strains. We have nevertheless found that Paecilomyces sp. isolated in this study presents good enzymatic diversity with the production of different classes at a time.

Fungi constitute a quite complex eukaryotic kingdom. In regard to their taxonomy. the differentiation of phylogenetically close species requires sometimes more than a DNA barcode (Glass \& Donaldson. 1995; Stielow et al.. 2015) and the comprehension of their enzymatic machinery is related to the basic knowledge from their mechanisms of resistance and adaptation.

\section{CONCLUSIONS}

The plant materials used in this work from the region of Meknes are very interesting biotopes for the isolation and selection of high performing ligno-cellulolytic filamentous fungi. The results of this investigation demonstrated the potential of the mycological wealth of the region. an important starting point for thinking out and developing new green local activities. The use of fermentation bioprocesses for generating highvalue molecules through the conversion of agricultural biomass and by-products is actually a proficient perspective. We further want to compare the kinetics of production of cellulases and ligninases of performant fungal species using different biomass sources and to optimize their enzyme production in bioreactor liquid culture.

\section{Bibliography}

Archer D.B.. Connerton I.F. \& MacKenzie D.A.. 2008. Filamentous fungi for production of food additives and processing aids. Adv. Biochem. Eng. Biotechnol.. 111(February). 99-147.

Bast F.. 2013. Sequence similarity search. multiple sequence alignment. model selection. distance matrix and phylogeny reconstruction. Nat. Protocols. 1-4. DOI: $10.1038 /$ protex.2013.065

Berrin J.-G. et al.. 2012. Exploring the natural fungal biodiversity of tropical and temperate forests toward improvement of biomass conversion. Appl. Environ. Microbiol.. 78(18). 6483-6490. DOI: $10.1128 /$ AEM.01651-12

Blanchette R.A.. 1984. Screening wood decayed by white rot fungi for preferential lignin degradation. Appl. Environ. Microbiol.. 48(3). 647-653.

Chandra R.. Takeuchi H. \& Hasegawa T.. 2012. Hydrothermal pretreatment of rice straw biomass: a potential and promising method for enhanced methane production. Appl. Energy. 94. 129-140.

Das H. \& Kumar Singh S.. 2004. Useful byproducts from cellulosic wastes of agriculture and food industry - a critical appraisal. Crit. Rev. Food Sci. Nutr.. 44(2). 7789.

Edgar R.C. \& Batzoglou S.. 2006. Multiple sequence alignment. Curr. Opin. Struct. Biol.. 16(3). 368-373.

El Bergadi F. et al.. 2014. Cellulolytic potential and filter paper activity of fungi isolated from ancients manuscripts from the Medina of Fez. Ann. Microbiol.. 64(2). 815822.

Ennadir J. et al.. 2012. Qualité microbiologique des farines de blé consommées au Maroc. Rev. Can. Microbiol.. 58(2). 145-150.

Eriksson K.-E.L.. Blanchette R.A. \& Ander P.. 1990. Microbial and enzymatic degradation of wood and wood components. Springer-Verlag.

Ghose T.K.. 1987. Measurement of cellulase activities. Pure Appl. Chem.. 59(2). 257-268.

Glass N.L. \& Donaldson G.C.. 1995. Development of primer sets designed for use with the PCR to amplify conserved genes from filamentous ascomycetes. Appl. Environ. Microbiol.. 61(4). 1323-1330.

Gregory T.R.. 2008. Understanding evolutionary trees. Evol. Educ. Outreach. 1(2). 121-137.

Hajjaji A.. Bouseta A.. Lebrihi A. \& Collin S.. 2004. Évaluation de la production de l'ochratoxine A par quelques espèces fongiques d'origine marocaine isolées à partir de grains de céréales. In : Actes du Congrès International de Biochimie. 3-6 mai 2004. Marrakech. 482-486.

Hall B.G.. 2013. Building phylogenetic trees from molecular data with MEGA. Mol.Biol.Evol.. 30(5). 1229-1235.

Hamelinck C.N.. Van Hooijdonk G. \& Faaij A.P.. 2005. Ethanol from lignocellulosic biomass: techno-economic performance in short-. middle- and long-term. Biomass Bioenergy. 28(4). 384-410.

Hariharan S. \& Nambisan P.. 2013. Optimization of lignin peroxidase. manganese peroxidase and laccase production from ganoderma lucidum under solid state fermentation of pineaple leaf. BioResources. 8(1). 250271.

Hefwany M.A. et al.. 2017. Optimization of culture condition for enhanced decolorization of direct blue dye by Aspergillus flavus and Penicillium canescens. J. Appl. Pharm. Sci.. 7(2). 83-92.

Kircher M.. 2012. The transition to a bio-economy: national perspectives. Biofuels Bioprod. Biorefin.. 6(3). 240245.

Kirk O.. Borchert T.V. \& Fuglsang C.C.. 2002. Industrial enzyme applications. Curr. Opin. Biotechnol.. 13(4). 345-351.

Maheshwari R. \& Navaraj A.. 2008. Senescence in fungi: the view from Neurospora. FEMS Microbiol. Lett. 280(2). 135-143. 
Mansouri A. et al.. 2014. Mycoflora and patulin-producing strains of cereals in North-Western Morocco. South Asian J. Exp. Biol.. 4(5). 276-282.

MAPM (Ministère de l'Agriculture et de la Pêche Maritime). 2017. Statistics of the national plant production. Rabat: MAPM.

Miller G.L.. Blum R.. Glennon W.E. \& Bruton A.L.. 1960. Measurement of carboxymethylcellulase activity. Anal. Biochem.. 2. 127-132.

Ministry of Environment. 2016. Focus on the region of Ifrane. www.environment.gov.ma. (4 October 2019).

O’Donovan A.. Gupta V.K. \& Tuohy M.G.. 2013. Fungal specimen collection and processing. In: Gupta et al.. eds. Laboratory protocols in fungal biology. Current methods in fungal biology. Springer Science+Business Media. LLC. 67-72.

Olukosi O.A.. Sands J.S. \& Adeola O.. 2007. Supplementation of carbohydrases or phytase individually or in combination to diets for weanling and growing-finishing pigs. J. Anim. Sci.. 85(7). 1702-1711.

Pitt J.I. \& Hocking A.D.. 2009. Fungi and food spoilage. Springer Science+Business Media. LLC.

Pointing S.B.. 1999. Qualitative methods for the determination of lignocellulolytic enzyme production by tropical fungi. Fungal Divers.. 2. 17-33.

Rodriguez A. et al.. 1996. Degradation of natural lignins and lignocellulosic substrates by soil-inhabiting fungi imperfecti. FEMS Microbiol. Ecol.. 21(3). 213-219.

Roussos S. et al.. 2006. Mycoflore naturelle des olives dans les maâsra et pouvoir toxinogène des souches d'Aspergillus sur céréales. Rabat : Actes Éditions. 175192.

Singhania R.R. et al.. 2010. Advancement and comparative profiles in the production technologies using solid-state and submerged fermentation for microbial cellulases. Enzyme Microb. Technol.. 46(7). 541-549.
Stielow J.B. et al.. 2015. One fungus. which genes? Development and assessment of universal primers for potential secondary fungal DNA barcodes. Persoonia. 35. 242-263.

Visser H. et al.. 2011. Development of a mature fungal technology and production platform for industrial enzymes based on a Myceliophthora thermophila isolate. previously known as Chrysosporium lucknowense $\mathrm{C} 1$. Ind. Biotechnol.. 7(3). 214-224.

Wertz J.L.. 2010. La lignine - Note de synthèse. Gembloux. Belgique : ValBiom.

White T.J.. Bruns T.. Lee S.\& Taylor J.. 1990. Amplification and direct sequencing of fungal ribosomal RNA genes for phylogenetics. In: Innis M.A.. Gelfand D.H.. Sninsky J.J. \& White T.J.. eds. PCR Protocols: a guide to methods and applications. Academic Press Inc.. 315-322.

$\mathrm{Xu}$ F. et al.. 2013. Qualitative and quantitative analysis of lignocellulosic biomass using infrared techniques: a mini-review. Appl. Energy. 104. 801-809.

Yang S.Q. et al.. 2006. High-level of xylanase production by the thermophilic Paecilomyces thermophila J18 on wheat straw in solid-state fermentation. Bioresour. Technol.. 97. 1794-1800.

Zerva Alexander A. et al.. 2014. Evaluation of Paecilomyces variotii potential in bioethanol production from lignocellulose through consolidated bioprocessing. Bioresour. Technol.. 162. 294-299.

Zhao Z.. Liu H.. Wang C. \& Xu J.-R.. 2013. Comparative analysis of fungal genomes reveals different plant cell wall degrading capacity in fungi. BMC Genomics. 14(1). 274-288.

Zyani M. et al.. 2009. Cellulolytic potential of fungi in wood degradation from an old house at the Medina of Fez. Ann. Microbiol.. 59(4). 699-704.

(41 ref.) 